Positive psychology school-based interventions: a reflection on what has been achieved so far and the work yet to be done.

\author{
Alicia R Chodkiewicz, \\ School of Education, University of New England, Armidale, Australia \\ *Christopher Boyle \\ School of Education, University of New England, Armidale, Australia
}

*Address for correspondence:

Christopher Boyle

School of Education

University of New England

NSW 2350

Australia

chris.boyle@une.edu.au

Word Count: 13, 170

Keywords: educational psychology, school interventions, positive psychology, positive youth development

Running Head: Positive psychology school-based interventions 


\begin{abstract}
An increased interest in youth development has shined the spotlight on the wellbeing, academic thriving and mental health of children and young people. With a rejuvenated interest in positive youth development and a plethora of research over the past few decades we are beginning to appreciate some of the complexities of learning and development across the years one spends at school. Alongside this trend the rise of positive psychology is changing our conception of youth, education and development. The ground swell of support for a new era of child centric teaching practices dedicated to student wellbeing enhancement has come from not only researchers and psychologists, but also schools and governments themselves who are showing an increased appetite for integrating positive psychology based programs into the learning curriculum. However while researchers are beginning to express cautious optimism regarding the effectiveness of such interventions, a large disparity exists between the initiatives being researched and those that are being taught in classrooms. The logistical constraints relating to limited resources, overcrowded curriculums, accessibility of information, teacher factors and quality training all play a role in shaping the effectiveness with which an intervention is implemented. This article reflects on the development of positive psychology school-based programs within the modern context and offers insights into how these initiatives can be enhanced to reach a wider demographic of youths and be translated more effectively into classrooms.
\end{abstract}

A note about gender used in this article-we have opted for the male pronoun to include both males and females. 
Positive psychology school-based interventions: a reflection on what has been achieved so far and the work yet to be done.

The current educational context

The $21^{\text {st }}$ Century has bought with it new pedagogies and teaching practices and the age of inclusive education has led to increased differentiation and learning support within classrooms (Boyle \& Topping, 2012). As the world's population swells there is growing pressure on schools to support a rising number of students. This has led to increases in class size (Berliner \& Glass, 2014). However what would undoubtedly strike most of us about the changing face of education is the new role played by technology. With the rise of the Internet and the birth of the digital age, schools are increasingly integrating technology into classrooms to support teaching practices and provide students with a new set of skills now required of the modern workforce. Smart boards, laptops and tablets are changing the way students engage with their learning, while online software and internet platforms give students unlimited learning opportunities at their finger tips (Stevenson, 2013).

Among the vastness of educational reforms one element has remained the same across generations - the goal of schools to equip students with the necessary academic skills for success. As a matter of fact it seems that we as a society have become even more invested in this goal. This was most poignantly seen when the USA passed the ground-breaking No Child Left Behind Act of 2001 (Rudalevige, 2003) in a move to establish a high set of learning standards and measurable academic goals for all students. The rippling effects of this educational reformation have been felt across the globe. Schools are now not only being expected to provide a high standard of education, but to show that each student is learning and retaining these 
skills as well, heralding in the era of high-stakes testing. School students are increasingly being asked to sit exams designed to assess students' and schools' ability to meet educational standards both nationally and internationally (Connolly, Klenowski, \& Wyatt-Smith, 2012). While there are definite benefits to such assessments, they are also fraught with unintentional negative implications. For one, such testing has been accused of distorting the priorities of schools (Hursh, 2008; Popham, 2001; Powers, Bowen, \& Bowen, 2010), as schools that are ranked and compared by test results, such as PISA, may shift their gaze towards improving student test performance at the expense of other important skills. Some have also questioned the impact that examination pressure may have on young students who may not have developed the skills to manage high levels of stress (Cefai \& Cavioni, 2015; Polesel, Dulfer, \& Turnbull, 2012).

As a final note on the changing face of education, consider that students of today are spending more time at school than ever before. An increased emphasis on education and qualifications has meant that more students are finishing high school and moving on to tertiary education. The Grattan Institutes 2014/15 analysis of the Australian tertiary education system reported rapid growth in student enrolments over the last 30 years (Norton \& Cherastidtham, 2014). With almost one million Australians enrolled in tertiary studies at higher education institutes, the proportion of young people currently studying is more than double that of the 1980s. However not all of societies progress has been in a positive direction.

Almost everything is better now than it was 50 years ago....there is more education, more music, and more women's rights, less racism, less pollution, fewer tyrants, more entertainment, more books, and fewer soldiers dying on the battlefield. Everything is better, that is, everything except human morale. Depression and anxiety are rampant, 
and average individual and average national happiness ... has not remotely kept up with improvements in the world (Seligman, Ernst, Gillham, Reivich, \& Linkins, 2009, p. 294).

It seems the greatest paradox of our time is the seemingly inverse relationship between social progress and mental health. Despite the reforms in education and schooling, children and young people are also showing increased psychological distress and mental illness (Oades, Robinson, \& Green, 2011; Woods \& Pooley, 2015). The Australian Government's 2015 report into the mental health of children and adolescents revealed $13.6 \%$ of individuals aged $4-11$ years were affected by mental illness within any 12 month period, with anxiety disorder and ADHD being the most common. In older individuals, aged $12-17$ years, the prevalence rises to $14.4 \%$, with a noted increase in incidence of major depressive disorder (Lawrence et al., 2015). Many feel that modern society has in fact resulted in children and youths being faced with more stressors than ever before (Bothe, Grignon, \& Olness, 2014; Powers et al., 2010).

In 2015 the Australian Broadcasting Corporation surveyed 20,000 youths aged $6-16$ to find out how much children worry (Blumer, 2015). Results showed that $62 \%$ of youths worry at least sometimes, with $20 \%$ reportedly worrying most of the time or always. The report also revealed that worries typically increase as one gets older, with $38 \%$ of youths aged 16 years reporting a high level of overall worry.

While the statistics and research is warning of a mental health epidemic across the developed world, at the same time people of today are increasingly infatuated with the pursuit of happiness. Whitley, Huebner, Hills, and Valois (2012) wrote that our obsession with happiness is evident from the thousands of self-help books, DVDs, 
workshops, and life coaches now available to consumers. A search of the online UK bookstore amazon.co.uk produced 20,854 self-help books about happiness (search made on 10.01.2016). Parents have not been immune to the happiness craze. Diener and Lucas (2004) asked over ten thousand adults from 48 countries across six continents about the hopes for their children. Their research found that across the globe adults consistently desired a high level of happiness for their children. With the increased attention being placed on happiness, Lyubomirsky (2007) claims that happiness is being lifted from the class of 'fad' to being considered a 'serious, legitimate and worthy aim' (p.2). He is not the only one who sees the worth in the happiness concept; with happiness being defined as both a positive catalyst for personal improvement and a positive outcome in itself (Kirkpatrick, 2015; Mulnix \& Mulnix, 2015).

With the roots of adult happiness said to form in childhood (Seligman, Reivich, Jaycox, Gillham, \& Kidman, 1995) ‘wellbeing' is becoming a $21^{\text {st }}$ Century buzzword now part of the everyday vernacular within educational circles. It is nowadays the aim of most modern schools to build resilience and maximize wellbeing among students. While some simplistically equate the term wellbeing with happiness not everyone supports this one-dimensional view. Dodge, Daly, Huyton, and Sanders (2012) dedicated their article to debating 'The challenge of defining wellbeing', concluding, 'Wellbeing is when individuals have the psychological, social and physical resources they need to meet a particular psychological, social and/or physical challenge' (p. 230). Such a definition of wellbeing shifts the axis toward how well an individual functions not just how happy they are (Richards \& Huppert, 2011). By doing so wellbeing can be more successfully measured and meaningfully 
operationalized, especially when it comes to fostering wellbeing, or optimal functioning, in children and young people.

Clearly educating students of today is markedly distinct from the classrooms of yesterday. With the change in practices, technologies, policies and trends it is important that our education system is flexible to meet the learning needs and challenges of tomorrows students. Society is currently left looking for ways to support the needs of a generation of youths experiencing increased stress and mental illness, meet societies demands for optimal happiness and instil youths with tools needed for success. We are now more than ever before looking to researchers in the fields of education and psychology to better understand the correlates of learning, thriving and positive developmental trajectories (Boonen, Pinxten, Van Damme, \& Onghena, 2013; De Castella, Byrne, \& Covington, 2013; Yeung, Craven, \& Kaur, 2014).

The complexities of learning and development during preadolescence

Students in elementary school, high school, and university... are required to apply themselves over a sustained period of time to develop their academic skills, engage with key performance demands, negotiate the rigors of competition, deal with setback and adversity, cope with possible self-doubt and uncertainty, and develop psychological and behavioural skills to effectively manage the ups and downs of the ordinary course of academic life (Martin, 2009, pp. 794-795).

The time one spends in school is a crucial phase, shaping the adult that one eventually becomes and setting the foundations on which one's life is built. How young people learn and develop across this period is both fascination and complex. A multitude of interrelated factors influence each child's developmental course and academic growth (Bronfenbrenner \& Bronfenbrenner, 2009; Martin, Nejad, Colmar, 
\& Liem, 2013; Weiner, 2010). The schools that one attends, the teachers one has, the level of support one receives from parents, the wider community in which one grows and one's own internal abilities, attitudes and aspirations all play a main role. Within this larger picture the separate stages of development and learning bring with them unique sets of challenges. While there are distinct features that resonate across the span of an individual's schooling, this article focuses primarily on characteristics of learning specific to preadolescence.

Preadolescence in Australia marks the time in which youths are coming to the end of their primary school education and moving into the early years of high school. By this stage young people already have experiences of formal education. These early educational and life experiences come to form the basis on which preadolescents build their self-perceptions. Research shows that students who have had a negative experience of learning due to repeated failure or disappointment have significantly lower self-perceptions compared to their more successful classmates (Au, Watkins, \& Hattie, 2010; Weiner, 2010). It is widely recognized that students who have experienced learning difficulties are at a higher risk of developing negative selfperceptions during this stage (Au et al., 2010; Núñez et al., 2005). What is equally influential is the relative nature of success. We are increasingly understanding how social comparison, as opposed to pure achievement, defines accomplishments. The little fish big pond effect shows that even academically strong students can perceive themselves to be failing in a high achieving environment (Bakadorova \& Raufelder, 2014; Fisher, 2014; Pinxten et al., 2015). A student compares himself to his classmates, siblings and friends when deciding on his own worth and often feels disappointed if he does not meet their level of success. Marsh et al. (2015) research found the negative effects of class comparison to be present in both $4^{\text {th }}$ and $8^{\text {th }}$ graders 
across schools in 13 countries. By the time a student reaches adolescents, therefore, his complex history of success and failure experiences has already played a key role in forming his self-identity and perception of himself as a learner (Weiner, 2010).

Preadolescence is also marked by a shift in the style of educational instruction and the learning demands placed on students. During this time learning material becomes more complex and study becomes increasingly self-guided. With increased workloads and a new emphasis on independent study students need to develop healthy study behaviors and self-regulatory skills (Boiché \& Stephan, 2014).

While research shows that psychological factors influence learning from an early age (Fyrstén, Nurmi, \& Lyytinen, 2006), it can be argued that these factors start to have their greatest impact during this preadolescent period. Let's take for example motivation. It is widely accepted that a student will learn best when he is motivated to do so (Boiché \& Stephan, 2014; Richardson, Abraham, \& Bond, 2012). Much of the sticker charts, principal awards and achievement certificates awarded to students throughout primary school are a way of motivating those students to learn. However as students get older they are required to be intrinsically motivated, to want to learn for learning sake. This is important as motivation has been linked to how engaged a student is in the learning process, how much effort he will exert, the time he spends on a task and how likely he is to persist in the face of difficulty (Boiché \& Stephan, 2014; De Castella et al., 2013; Richardson et al., 2012). A student's ability to maintain motivation during preadolescence and into higher-level education is therefore an important factors shaping ones future success.

Lastly, preadolescence is a time of physical, social and emotional change. It is a time where individuals start becoming increasingly independent. A time when the 
main influence in a young person's life shifts from his parents to his peers (Ohl, Fox, \& Mitchell, 2013). Each individual is aware of the changes and challenges that accompany adolescence because we all experienced them first hand. Schonert-Reichl et al. (2015) believes that the thinking patterns one forms in preadolescence solidifies as one moves into adolescence and becomes harder to change as that person grows older. Evidence also shows that school disengagement and mental health issues spike in adolescence (Bakadorova \& Raufelder, 2014; Horn, Pössel, \& Hautzinger, 2011; Madden, Green, \& Grant, 2011). Preadolescence may therefore be a crucial time in which an individual's learning and developmental path is being paved. As such a better understanding of this developmental stage will be important when endeavouring to induce positive growth in lifelong wellbeing and functioning.

The first steps to fostering student wellbeing

When researchers discuss fostering increased youth wellbeing their discourse typically falls into two distinct categories: bolstering academic success or reducing mental illness. Both of these areas are of importance to the experience of youths. Before a researcher can begin fostering increased wellbeing, he must first understand the psychological and behavioural correlates related to learning and healthy development, as these hold the key to designing an effective psychology-based intervention.

The last 50 years has seen an influx of research looking to understand the factors that optimize learning and increase academic achievement. It is now widely accepted that over and above a student's underlying cognitive ability, emotional and psychological characteristics play a defining role in shaping academic outcomes (Bandura, 1978; Martin, 2007; Weiner, 1979). Of all the academic correlates studied 
self-perceptions have arguably received the most attention, and for obvious reason. When making the decision to learn, to dedicate considerable time and effort to a task that may or may not be intrinsically enjoyable, a student is faced with answering one poignant question, 'do I have the ability to achieve this goal?' A student who answers yes to this question is more likely to work hard and achieve highly (Bakadorova \& Raufelder, 2014; Pinxten, Marsh, De Fraine, Van Den Noortgate, \& Van Damme, 2014). Alternatively a student who does not believe he has the abilities needed to succeed is more likely to disengage from the learning activity and experience more academic challenges (De Castella et al., 2013; Schwinger, Wirthwein, Lemmer, \& Steinmayr, 2014). Studies have overwhelmingly supported this notion finding a strong positive correlation between favourable self-perceptions and academic success (Arens, Yeung, Craven, \& Hasselhorn, 2011; Banks \& Woolfson, 2008; BodkinAndrews, O'Rourke, \& Craven, 2010; Marques, Pais-Ribeiro, \& Lopez, 2011; Pinxten et al., 2014; Yeung et al., 2014). Clearly believing that you are capable helps you take the first curial steps on the way to success, it is however not the only step one has to take. There now exists a large body of work dedicated to identifying the ideal factors linked to healthy learning. High academic success has been linked to students who are highly motivated (De Castella et al., 2013; Yeung et al., 2014), set positive goals (Yu \& Martin, 2014); hold optimistic future expectations (Boonen et al., 2013; Fyrstén et al., 2006; Marques et al., 2011); use healthy reasons to explain events (Chodkiewicz \& Boyle, 2015; Chodkiewicz \& Boyle, 2014); have the ability to self-regulate (Boiché \& Stephan, 2014; Drake, Belsky, \& Fearon, 2014); and are adaptable to new learning situations (Martin et al., 2013).

As in the area of learning, researchers studying mental health have been looking to better understand the psychological and emotional factors that play a role 
in the development of disorders. Identified correlates include self-regulation (Baker et al., 2012; Holen, Lervåg, Waaktaar, \& Ystgaard, 2012; Zimmerman, Phelps, \& Lerner, 2008), self-perceptions and life satisfaction (Marques et al., 2011), explanation styles and expectations for the future (Au, Watkins, Hattie, \& Alexander, 2009; Seligman, Schulman, \& Tryon, 2007) as well as maladaptive thinking patterns (Punamäki, Paavonen, Toikka, \& Solantaus, 2013) and positive emotions (Richards \& Huppert, 2011). If any of these seem familiar, that is because (not surprising) many of the factors positively correlated with optimal learning are also important for healthy mental development. A lack of- or maladaptive profile on- these elements increases the risk of a young person developing a mental illness.

There is optimism in the research field regarding the malleability of many of these constructs, with the belief that mental illness in young people can be prevented and youth functioning along with academic achievement can be improved (Punamäki et al., 2013). Martin Seligman has been leading the charge in preventative youth programs aimed at reducing young peoples' risk of developing depression and anxiety, with promising results (Seligman, 2002; Seligman et al., 2009; Seligman et al., 2007). Seligman's work has shown that if we can change thinking at a young age we can also change the trajectory of youth mental health. The evidence highlights the need for youth support in: developing positive self-perceptions and adaptive thinking styles; learning to set constructive goal and make healthy future predictions; and build skills to help manage emotions and cope with difficulty (Madden et al., 2011; Pinxten et al., 2014; Weiner, 2010; Yu \& Martin, 2014). Such a program of youth support have developed within the field of positive psychology and promise to enhance student learning, preventatively tackle the issue of youth mental disorder and arm the next generation with life skills to help them flourish. 
What does positive psychology have to offer schools?

Growing recognition of the need for youth program has arisen alongside the rise of positive psychology. This is by no means a coincidence as positive psychology personalities, such as Martin Seligman, have been instrumental in promoting and developing youth support programs. So what is positive psychology?

To answer this question we first need to take a look back at the history of psychology to uncover the antecedent of the positive psychology movement. In his paper 'Positive psychology, positive prevention and positive therapy' Seligman (2002) recounts that the last 100 years has seen marked change in the field of psychology. Seligman writes that before the 1930s the field of psychology was driven by three central desires: to cure mental illness; to improve productivity and life fulfilment; and nurture talent. Following WWII the model of psychological practice transformed to take on the scientific medical model familiar to mental health practitioners today. In doing so the focus of psychology became restrictive, concentrating almost exclusively on mental illness and pathology (Seligman, 2002; Vella-Brodrick, 2011). In 1954 Maslow eloquently encapsulated the shift in psychology of his time,

The science of psychology has been far more successful on the negative than on the positive side. It has revealed to us much about man's shortcomings, his illness, his sins, but little about his potentialities, his virtues, his achievable aspirations, or his full psychological height. It is as if psychology has voluntarily restricted itself to only half its rightful jurisdiction, and that, the darker, meaner half.

(Maslow, 1954, p. 354) 
One of the central criticisms of psychology at the time was that the research and theories failed to acknowledge a large and significant part of people's lives, that of positive emotions and functioning (Lewis, Huebner, Reschly, \& Valois, 2009). Additionally, in the midst of this period child and adolescent psychology as a discipline was far from the minds of most in the field. In 1977 Lipsitz wrote a review claiming youths were simply forgotten, reasoning that a failure to promote mental health and positive development among young people resulted from a pervasive acceptance of the inevitability of youth difficulties.

The end of the $20^{\text {th }}$ Century, however, marked a change in the breeze. Seligman's inaugural speech as the president of the American Psychological Association in 1998 can be viewed as marking the birth of positive psychology (Vella-Brodrick, 2011). Seligman proposed a new form of psychology to swing the pendulum back in the positive direction by building 'what is right' not just fixing 'what is wrong'. Seligman proclaimed positive psychology as the study and proliferation of characteristics such as: wellbeing, satisfaction, joy, happiness, optimism, hope and faith, positive personal traits, perseverance, interpersonal skills, nurturance and tolerance (Fowler, Seligman, \& Koocher, 1999). While the fundamental concepts underlying positive psychology were not in themselves new in 1998, Seligman's speech was instrumental in rejuvenating the ideas and inspiring twenty years of new theory and innovation (Vella-Brodrick, 2011).

Positive psychology quickly gained a strong following within the psychological community and strong interest from the general public (Vella-Brodrick, 2011). People were inspired by the emphasis on positive emotions and flourishing, along with the idea that every individual is born with personal strengths and 
potentialities. Such thinking gave birth to a flourish of research investigating happiness and wellbeing along with theories mapping the positive correlates of healthy development, such as the 5 C's model (competence, confidence, character, connection and caring; Lerner, von Eye, Lerner, Lewin-Bizan, \& Bowers, 2010). The Character Strengths and Virtues (CSV) handbook (Peterson \& Seligman, 2004) was also designed to provide a descriptive manual of positive human characteristics in stark contrast to the existing manual of pathology, the Diagnostic and Statistical Manual of Mental Disorder (DSM5; American Psychiatric Association, 2013). The proponents of positive psychology were also instrumental in advocating for a preventative model, where individual strengths are supported and adaptive skills are taught to promote healthy and positive development (Seligman, 2002; Seligman, Railton, Baumeister, \& Sripada, 2013; Terjesen, Jacofsky, Froh, \& Digiuseppe, 2004). Many saw the value in giving individuals' skills to deal with problems before they arise instead of trying to fix things after they are broken, leading to a growing industry of preventative programs and interventions (Owens \& Patterson, 2013; Seligman et al., 2007; Sin \& Lyubomirsky, 2009).

Positive psychology has however not been without its' critics. The field has been accused of focusing too singularly on happiness. One cannot always be happy, rather happiness is an emotion that is by nature a relatively short-lived reaction to life events (Lundqvist \& Kenttä, 2010). The simple promotion of the positive has been questioned by findings that suggest promoting the good does not simply reduce the bad (Lerner et al., 2010), but rather positive and negative emotions are fundamentally different in nature (Coffey, Warren, \& Gottfried, 2014; Lundqvist \& Kenttä, 2010). Lazarus (2003) in his scathing review 'Does the positive psychology movement have legs?' criticized the simplistic practice of categorizing emotions into bipolar valence 
labels, positive and negative, claiming that such a practice is 'unwise and regressive' (p. 99). Lazarus (2003) rather states that every emotion can have a positive or negative valence shaped by the context and situation in which it occurs. Debate has also surrounded positive psychology's manual of character strengths and virtues, questioning who has the authority to define a set of virtues ascribed to be optimal across the globe (Miller, 2008). Aside from problems associated with the authoritarian nature of such a venture, the vastness of cultural and religious interpretations of desired virtues makes the task of setting a globally applicable set of standards seem naïve at best (Sandage \& Hill, 2001). Frawley (2015) reviewed two decades worth critical responses to positive psychology, noting others' assertions that positive psychology is incoherent, fraught with measurement issues, lacking evidence to support grandiose claims and simply 'bad science'.

Supporters of positive psychology, on the other hand, have appealed for the discipline to be seen as an umbrella under which theory and research are linked through the shared pursuit of common goals. Vella-Brodrick (2011) defined these goals as: fostering an optimal level of individual and collective wellbeing; equipping individuals with the strengths and skills needed to face the challenges of everyday life; and mitigating dysfunction through a preventative model. While one can reflect on the potential shortcomings of the positive psychology movement and hope for maturation in the field, one cannot deny the swell of mass support the movement has attracted and the glaring fact that positive psychology is here to stay. The time is ripe to infuse positive psychology ideas and techniques into current practice, no place more so than in schools where positive psychology has been pushing for the promotion of optimal functioning and improved quality of life for the next generation (Huebner \& Kimberly, 2011). 
How is the implementation of positive psychology initiatives working in schools?

The turn of the $21^{\text {st }}$ Century was crucial in shaping the course of future educational policies. The changing view of youth that came with the rise of positive psychology, the increased awareness of the psychological and emotional correlates of learning and the move towards a preventative model of mental health spurred the wheels of change into motion (Miller, Short, Garland, \& Clark, 2010). Discussion turned towards a more holistic view of students and education, with many advocating for educators to go beyond simply teaching academics to supporting the development of the whole child (Oades et al., 2011; Waters, 2011). Ever increasingly schools are being urged to take on a larger role in the support of student mental health and the nurturing of social, emotional and psychological skills. Schools have been asked to transform their curriculums and teaching practices to increase students wellbeing and happiness (Lewis, Huebner, Malone, \& Valois, 2011), foster optimal youth functioning (Earhart et al., 2009), teach social skills (Schonert-Reichl et al., 2015), support student self-image, equip students with higher level cognitive skills (Waters, 2011) and tackle the issue of youth mental health (Seligman et al., 2007).

It is not just the fields of academia that has been calling for an increased role of schools in supporting positive youth mental health, a shift in rhetoric and government policies towards education is also being seen (Askell-Williams, Dix, Lawson, \& Slee, 2013; Cheney, Schlösser, Nash, \& Glover, 2014). The United Kingdom have established the Social and Emotional Aspects of Learning (SEAL) program (Hallam, 2009) while the United-States have initiated the Collaborative for Academic, Social and Emotional Learning (Jones \& Bouffard, 2012). In Australia similar policy changes are being seen. The Council of Australian Governments 
(Council of Australian Governments, 2013) pledged extra support for youth mental health programs in schools and outlined a number of initiatives being made around the country to better support youth development and reduce mental illness. One such initiative includes the Department of Educations (Department of Education NSW, 2015) 'wellbeing for school' released in 2015. In light of such progress Cefai and Cavioni (2015) postulate that mental health promotion in schools is becoming a permanent fixture of our education system.

As a result over the past two decades schools have been increasingly incorporating positive psychology ideas into the classroom (Madden et al., 2011; Nielsen et al., 2015). First, let's take a moment to consider why schools are at the centre of these discussions. The research community is unanimous - school is the ideal location for positive psychology interventions supporting the development of youths (Askell-Williams et al., 2013; Bothe et al., 2014; Cefai \& Cavioni, 2015; Cheney et al., 2014; Mychailyszyn, Brodman, Read, \& Kendall, 2012; Nielsen et al., 2015). For one a large proportion of a young person's waking hours are spent at school (Neil \& Christensen, 2009; Seligman et al., 2009). Consequently schools offer an ideal platform to reach the widest possible population of youths (Bothe et al., 2014; Cheney et al., 2014; Nielsen et al., 2015). Integrating positive psychology programs into schools is also cost effective (Baker - Henningham \& Walker, 2009; Bothe et al., 2014), as existing resources and personnel can be utilized to reduce additional costs associated with running new initiatives. Research is also showing the monetary advantages of school-based prevention, finding that the cost of running preventative programs is much cheaper than the subsequent costs associated with later mental health care. Cheney et al. (2014) reported that it is ten times more expensive to support the needs of a child experiencing mental health or behavioural difficulties 
than one that is not. It is also important to note that youths affected by mental illness are not always receiving the support they need and many who are engaged in a treatment may terminate this support prematurely (Cheney et al., 2014; Neil \& Christensen, 2009). School-based interventions offer the chance to provide help and support to a wider scope of students in need by breaking down the financial, practical and cultural barriers associated with external mental health services (Casserly, 2013; Miller et al., 2010). School is the place where a student experiences many of the ups and downs of life. Having these interventions implemented within the school context allows an intervention to meet students where they are (Owens \& Murphy, 2004) and model the techniques in a setting where students need them the most (Miller et al., 2010; Seligman et al., 2009). Lastly schools are a place of learning. Students are accustomed to learning new skills and techniques in schools making them potentially more open and ready to engage in interventions (Cheney et al., 2014; Neil \& Christensen, 2009).

Positive psychology school-based interventions, while diverse and varied, are united by a shared goal to improve the developmental trajectory of young people and prevent future difficulties by teaching skills to encourage positive self-perceptions, positive emotions and positive behaviours (Galassi \& Akos, 2004; Kuperminc, Thomason, DiMeo, \& Broomfield-Massey, 2011). There has been strong support for the implementation of these programs in schools. Cefai and Cavioni (2015) write such initiatives are 'leading to the formation of academically, socially and emotionally literate young people who have the skills, abilities and emotional resilience necessary to thrive in a challenging world' (p. 54). Collins, Woolfson, and Durkin (2013) postulate that, 'school based interventions... have the potential to alleviate multiple problems, as well as optimizing application of new skills learned as opportunities 
arise in the day to day life of the school' (p.86). Finally, Vella-Brodrick (2011, p. 12) states that the aim of positive education is to "transforms schools into places where assets such as empathy, optimism, creativity, self-efficacy and resilience are identified, appreciated and cultivated'. What follows is a concise summary of only a few of these school-based programs. This list is by no means exhaustive, given the breadth and number of interventions currently available.

Collins et al. (2013) implemented an intervention using cognitive behavioural therapy (CBT) techniques in the hope of improving students' coping skills and positive outcomes. In Scotland 182 students aged 9- to 10-years participated in ten intervention sessions, which explored topics such as the link between thoughts and emotions; positive self-statements; differentiating controllable and uncontrollable problems; and developing coping tools. Sessions were run by either classroom teachers or trained psychologists. By teaching problem solving strategies in a structured group program Collins et al. (2013) were able to successfully reduce anxiety among the students and increase the use of helpful coping skills. These improvements were also maintained when reassessed 6-months following the program.

Madden et al. (2011) piloted a strengths-based coaching program. The intervention was rooted within a solution-focused framework and set out to raise students' self-awareness of their own character strengths, identify new ways to use these personal resources and work through an adaptive cycle of self-regulation and goal setting. The sample of students included 38 males aged 10- to 11-years from Sydney, Australia. Each participating student attended eight group coaching sessions running for approximately 45-minutes. While this was a small-scale pilot study, the 
results were nevertheless promising, with participating students reporting increases in levels of engagement and hope. These findings are however limited by the lack of a comparison group and the failure to measure the maintenance of treatment effects following the conclusion of the program.

The 'Aussie optimism program' was designed for students in the seventh grade to encourage healthy thinking and social competencies (Roberts et al., 2010). The intervention was divided into two separate segments. The first ten weeks of the intervention were concentrated on educating students on thinking patterns and teaching coping skills based on CBT techniques, with the second half dedicated to the promotion of social skills. Following the program parents reported significantly lower levels of internalizing, but not externalizing, behaviours and fewer students were referred to external mental health services. However students themselves did not report any significant improvements. Of further concern to the researchers was the finding that improvements reported by parents were not maintain when measured again 6 months following the intervention, suggesting the improvements may be short lived (Roberts et al., 2010).

Taking a slightly different approach Horn and colleagues (2011) implemented the 'JES youth prevention program' hoping to improve student cognitions, learning behaviours and grades. The JES program taught adolescents about the links between emotions, stress and the body. The intervention was conducted with students in Grade 8 attending ten sessions running for approximately 45 minutes each. Each session included two-minutes of body warm-up exercises, comprising stretching and deep breathing, followed by a 20 minute discussion on topics related to emotional regulation and coping. The end of the sessions were reserved for students to spend on 
expressive writing tasks. Small academic improvements were seen following the program, however these were not maintained overtime. Notably students who attended the program showed a significant decrease in the number of days absent from school compared to students who did not participate in the sessions.

Finally, Owens and Patterson (2013) approached the task of supporting students' wellbeing in schools with a much more simplistic model. Everyday for a week 62 students recruited from several after school care and summer day camp programs were ask to spend time drawing. Students aged $5-11$ years were divided into three groups, one that drew pictures of something for which they were grateful, another depicted one's projected best possible selves, while their peers simply drew something done that day. In spite of the simplistic nature of this intervention the results were cautiously promising. Students who had spent the week imagining their best possible self showed a boost in self-esteem as measured by the Perceived Competence Scale for Children (Harter, 1982). No other measures of wellbeing (such as life satisfaction or affect) showed improvements for these students, and no changes at all were seen for the gratitude group. Owens and Patterson (2013) are not alone in believing that the simple act of reflecting on the positive may have a lasting impact (Froh, Kashdan, Ozimkowski, \& Miller, 2009; Froh, Sefick, \& Emmons, 2008; Suldo, Savage, \& Mercer, 2014), however like most of these interventions the effectiveness of such an approach is yet to be definitively confirmed.

While positive psychology youth programs are often more varied than they are similar, it is possible to see some parallel themes across the interventions. Firstly the bulk of youth programs have been targeted at late childhood and early adolescence. There are several reasons for this trend, one of which is the neural plasticity 
associated with youth. Late childhood and early adolescence is seen as a time when young brains are sufficiently developed to be able to effectively engage in the cognitive demands of internal reflection and thought restructuring associated with many of the psychology based programs (Schonert-Reichl et al., 2015). At the same time these young students promise a level of malleability and willingness to change not often seen in older populations when thinking patterns become increasingly entrenched (Lerner et al., 2010). This period of development is also seen as a crucial turning point before the decline in learning motivation and escalated risk of difficulty seen in adolescence (Bakadorova \& Raufelder, 2014; Madden et al., 2011). Programs teaching adaptive skills may be instrumental in helping youths manoeuvre through the treacherous adolescent years (Dubow, Huesmann, Boxer, Pulkkinen, \& Kokko, 2006; Horn et al., 2011; O'Connor et al., 2011).

Secondly, the majority of school-based interventions are short in nature, typically running for between 6 - 10 sessions (Chodkiewicz \& Boyle, 2015; Horn et al., 2011; Lavasani, Sharifian, Naghizadeh, \& Hematirad, 2012; Miller et al., 2010; Ohl et al., 2013; Stice, Rohde, Gau, \& Wade, 2010; Suldo et al., 2014). While some have bucked the trend and run much longer youth programs (140 lessons - Beets et al., 2008; 20 lessons - Roberts et al., 2010; 25 lessons - Seligman et al., 2009; 6 months - Toland \& Boyle, 2008) such interventions are far from the norm. Rather longer programs are often seen as time-consuming (Toland \& Boyle, 2008) and logistically impractical to fit in to an already full school curriculum (Chodkiewicz \& Boyle, 2014).

Finally, the majority of school-based interventions are firmly rooted within either a single or duo theoretical framework. A popular trend has been to model youth 
programs on the principals of CBT (Boyle, Topping, Jindal-Snape, \& Norwich, 2011; Collins et al., 2013; Stice et al., 2010; Woods \& Pooley, 2015). Being one of the most widely used contemporary therapeutic forms and shown to have positive effects on youth mental health (Dawood, 2013; Reynolds, Wilson, Austin, \& Hooper, 2012; Spielmans, Pasek, \& McFall, 2007), CBT is an obvious choice when designing psychological programs in schools. Other approaches have included attribution retraining (Chodkiewicz \& Boyle, 2015; Dresel \& Haugwitz, 2008); solution focused therapy (Madden et al., 2011); strength based coaching (Seligman et al., 2009); and mindfulness training (Huppert \& Johnson, 2010; Nidich et al., 2011; Schonert-Reichl et al., 2015). While some initiatives are taking a more comprehensive approach by combining various positive psychology interventions, such as the Wellness-Promotion Program (Suldo et al., 2014), such approaches remain few and far between.

The downside of interventions designed adhering to a singular theoretic framework is that the pool of possible techniques and skills accessible to each student are restricted. Furthermore such an approach reflects a naïve assumption that positive student development can be stimulated through a one size fits all intervention. Not surprisingly youths do not all follow the same developmental trajectory, with each individual holding his own set of strengths and facing a unique array of obstacles and challenges. As such Zimmerman et al. (2008) implored that school-based programs should be as rich and diverse as the student populations they are trying to inspire. When designing the school-based programs of the future we need to start looking to each other, to what has worked across the field, to develop diverse programs that do not simply teach a single skill, but rather endow youths with a tool kit of techniques to enrich and fortify their lives. 
The few researchers who have attempted to collate findings across studies have been cautiously optimistic that positive psychology school-based programs are leading to improvements and helping students thrive. The largest of these metaanalysis studies was a review by Durlak, Weissberg, Dymnicki, Taylor, and Schellinger (2011) of 213 Social and Emotional Learning (SEL) programs within schools. Durlak et al. (2011) concluded that SEL program did indeed enhance socialemotional skills along with positive attitudes and behaviours. A decrease in emotional distress and conduct problems was also attributed to the interventions. Contrary to findings by others (Dresel \& Haugwitz, 2008; Morris, 2013; Stice et al., 2010), Durlak et al. (2011) found that in general SEL programs maintained treatment effect over a 6-month period following intervention, albeit with noted reduction in the magnitude of effects. However Durlak et al. (2011) review excluded research based on targeted interventions, self-selection or small group programs. While whole class interventions may be ideal, such interventions are not always practically possible or theoretically warranted. Therefore Durlak et al. (2011) review may only show one small part of a much larger field of school-based interventions supporting youth positive development.

In a smaller-scale review Sin and Lyubomirsky (2009) collated data across 74 studies with a total of 6,047 students aimed at improving students wellbeing or preventing depression. The meta-analysis revealed both forms of intervention to be effective, crediting wellbeing interventions with a $96 \%$ effect size and depression interventions at $80 \%$. The authors concluded that positive psychology interventions were a viable and potentially a more effective alternative to standard treatments across the lifespan. In a similar vein Neil and Christensen (2009) reviewed 27 randomized controlled trials implementing school-based positive psychology 
programs aiming to prevent youth anxiety through building student resilience. The meta-analysis by Neil and Christensen (2009) supported the value of school-based programs finding that in three-quarter of research studies anxiety symptoms among youths decreased. Finally Waters (2011) carefully selected studies for review that represented a broad spectrum of positive psychology interventions, being implemented among diverse school populations and settings using large samples and covering five positive psychology foci (resilience, serenity, hope, gratitude and character strength). Based on the twelve interventions reviewed Waters (2011) endorsed the effectiveness of positive psychology interventions in schools concluding, 'taken together, the results are significant, robust and promising' (p. 83).

While the current reviews of interventions are overwhelmingly positive, one must keep in mind that this field of research is still in its' infancy, with only a limited number of comprehensive large-scale reviews available. It will not be until the discipline has matured and researchers have dedicated time to comprehensive and longitudinal research studies along with extensive meta-analyses that we will begin to know the true potential of school-based positive psychology program.

The teacher's role in implementing school-based initiatives and understanding implementation barriers

Once evidence-based interventions are developed and accepted by the research community they still needs to be implemented in schools to have a wide and meaningful impact (Mohammadi, Rowling, \& Nutbeam, 2010; Sanetti, Dobey, \& Gallucci, 2013). The Australian National Health Report released in 2013 reported that $37 \%$ of schools were implementing mental health frameworks, $52 \%$ were offering mental health programs while $64 \%$ were incorporating mental health literacy into 
their curriculum (Department of Health and Ageing, 2013). This leaves many schools across Australia still not as yet using positive psychology interventions. Even schools that do incorporate intervention programs do not always implement them correctly (Durlak, 2015; Evans, Murphy, \& Scourfield, 2015; Sanetti, Dobey, et al., 2013), with Forman, Olin, Hoagwood, Crowe, and Saka (2009) charging that the fidelity of positive psychology interventions is so low in real world contexts that positive effects are being severely mitigated. Clearly an intervention that is implemented correctly is going to have a far greater impact than one that is not. More needs to be done to assure that these positive initiatives are being accurately and effectively delivered within schools.

The low fidelity of intervention implementation in real world settings is a central concern to all researchers and educators working to improve the wellbeing and developmental trajectory of youths. Classroom teachers are typically found at the centre of discussions on school-based intervention implementation. There are many theoretical and logistical advantages of teachers running such programs in schools (Baker et al., 2012; Beycioglu, Ozer, \& Ugurlu, 2010; Miller et al., 2010). Classroom teachers have a monopoly on students' time while they are at school as well as having pre-existing rapport and influence over their students (Bakadorova \& Raufelder, 2014; Baweja et al., 2015; Collins et al., 2013; Gut, Reimann, \& Grob, 2013). Cost wise, it is much cheaper and sustainable in the long run for schools to use pre-existing personnel when implementing school-based initiatives (Bradshaw, Koth, Thornton, \& Leaf, 2009; Collins et al., 2013). Teachers also have the added advantage of continuous contact with the students outside of the prescribed intervention times, allowing them to promote the use of skills throughout the school day (Beets et al., 2008; Miller et al., 2010). Not only are teachers theoretically ideal, they are also 
typically the ones found running the programs within real world settings (Beets et al., 2008; Sanetti, Dobey, et al., 2013; Waters, 2011).

Nonetheless there remains questions over whether teachers can effectively implement psychological interventions, as Urhahne, Chao, Florineth, Luttenberger, and Paechter (2011) claims, 'teachers are not trained to focus on aspects outside of the area of student achievement' (p. 171). In an attempt to answer this question researchers have looked to compare the differences in student outcomes following teacher and expert led programs. Unfortunately a string of contradicting findings has made it impossible as of yet to definitely come to a conclusion on this issue. Some have raised concerns over the effectiveness of interventions implemented by teachers within schools (Forman et al., 2009; Horner \& Gaither, 2004; Pas \& Bradshaw, 2012; Sanetti, Dobey, et al., 2013). Others have found evidence supporting teachers' ability to effectively run psychological based interventions (Miller et al., 2010; Roberts et al., 2010; Ziegler \& Heller, 2000) concluding that they are just as skilled at implementing interventions as expert researchers. Some have even proposed that teachers may be superior to researchers because they are able to deliver a larger dose of the intervention throughout the school day (Collins et al., 2013; Durlak et al., 2011; Schuitema, Peetsma, \& van der Veen, 2014). A meta-analysis of twenty school-based programs by Neil and Christensen (2009) found teachers to be the better administrators, with a higher percentage of interventions led by teachers leading to significant outcomes, albeit with smaller effect sizes compared to researcher led initiatives.

As the debate rages on among the research community schools are the ones left having to piece together support programs for their students in an effort to 
promote optimal students wellbeing and development. Educators working within schools across the globe are trying to balance the recommendations of evidence-based best practice with the practical constraints and competing stakeholder agendas when trying to select and implement positive youth interventions (Fabiano, Chafouleas, Weist, Sumi, \& Humphrey, 2014). Unfortunately there currently exists an undeniable gap between research theory and educational practice when it comes to supporting youth positive development (Ahuja, 2012; Baweja et al., 2015; Bearman, Wadkins, Bailin, \& Doctoroff, 2015; Chodkiewicz \& Boyle, 2014). The reason for this lies in a multitude of differences between the idealistic research setting and the real world of schools and teachers. Barriers hindering the seamless implementation of interventions in schools are numerous and varied across settings. The barriers discussed in this section focus primarily on those at the teacher level and reduce the chance of teachers and schools implementing interventions effectively.

Access to information and knowledge regarding the newest innovations and evidence-based practices has been a long-standing barrier to intervention implementation in schools (Ahuja, 2012; Chodkiewicz \& Boyle, 2014). It seems a contradiction that researchers developing positive psychology school-based programs are publishing their works in coveted scientific and academic journals far removed from the real schools, teachers and students they are trying to benefit. In a study of teacher behaviours. Beycioglu et al. (2010) reported that approximately $32 \%$ of teachers have not read any research articles since graduating. Similarly Ahuja (2012) found $41 \%$ of teachers were not interested in research studies, while less than $20 \%$ of teachers prioritized reading research journals. Powers et al. (2010) made a poignant argument stating that teachers and schools often do not have subscriptions to journals or online databases needed to access information on the latest research findings. As a 
result instead of basing their classroom practices on evidence-base research, Miller et al. (2010) asserts that teachers prefer, 'whatever method they were trained in or simply what feels right' (p.88). Furthermore even if a teacher is lucky enough to read an academic article outlining a school-based intervention, the programs themselves are often poorly explained and therefore difficult to replicate (Nielsen et al., 2015; Sanetti, Dobey, et al., 2013), with teachers favouring interventions with easy to follow guidelines requiring minimal time and resources (Castro-Villarreal, Rodriguez, \& Moore, 2014). Fortunately with the rise of the Internet and a proliferation of educational resource publications the tides are slowly turning. There is growing information being made available to teachers, through online platforms such as ResearchGate offering free access to online publications. Furthermore new initiatives such as Australia's KidsMatter, which offers schools access to over 100 interventions, are bringing evidence-based mental health interventions into the educational domain (Askell-Williams et al., 2013; Powers et al., 2010; Wyn, Cahill, Holdsworth, Rowling, \& Carson, 2000).

Knowledge of available school-based interventions and programs is clearly a necessary first step for educators wanting to implement such initiatives in their schools (Castro-Villarreal et al., 2014). Equally important, however, is an educator seeing a need for such an intervention, have an understanding of the theorized outcomes associated with the program, and holding the belief that students will truly benefit (Baker - Henningham \& Walker, 2009; Durlak \& DuPre, 2008). With the ever-increasing demands being placed on teachers' time, educators need to weigh up whether the benefits to students are large enough to outweigh the time and resources required to run an intervention (Fabiano et al., 2014). Once the decision to run a school-based initiative has been made, teachers' perceptions and attitudes then come 
to impact how the program is implementation (Borrelli, 2011; Mohammadi et al., 2010). Teachers with positive attitude have been shown to administer a higher quantity and quality of program then their less positive colleagues (Beets et al., 2008). Teachers will also put more effort into implementation if they 'buy in' to the theory underlying the program and see the program as worthwhile (Forman et al., 2009). Castro-Villarreal et al. (2014) listed the important factors influencing teacher implementation quality as: motivation, knowledge and willingness to engage in the process. Just as self-belief is vital for student success, research has shown that a teacher's confidence in his own ability to successfully implement new programs directly correlates to the fidelity of implementation and student outcomes (Beycioglu et al., 2010; Durlak \& DuPre, 2008; Sanetti, Kratochwill, \& Long, 2013).

Given the way an individual's own attitudes and self-belief can shape their ability to effectively implement a school-based intervention these factors may hold the key to finding the ideal intervention leaders. The current debate over whether teachers or experts should run programs in schools was noted above. Weissberg, Kumpfer, and Seligman (2003) however challenged that it may not be the qualifications of an individual that defines their competence as a program leader, but rather their personal qualities such as: personal efficacy, warmth, relationship skills, humour, empathy and the skills in fostering positive learning environments. Similarly Neil and Christensen (2009) advocated a need to look at intervention parameters and program leader quality as prime influences on treatment effectiveness.

A mundane program that is incorrectly delivered by a disinterested and unprepared leader is likely to produce poorer results than one that is innovative, based on up-to date knowledge and delivered in an enthusiastic and engaging manner (Neil \& Christensen, 2009, p. 212). 
The key to facilitating integration and successful implementation of positive psychology interventions in schools may be through widespread distribution of teacher targeted information and high quality teacher-training programs (Ahuja, 2012; Bradshaw et al., 2009; Evans et al., 2015; Nielsen et al., 2015). Educating teachers on the importance of psychological factors in learning, highlighting the potential benefits of school-based programs and illustrating the concrete application of skills within the learning environment stands to greatly improve the number of schools effectively integrating positive psychology into the classroom. It seems that while all eyes are fixed on schools to improve implementation the research community needs to be doing more to understand how teachers can be best prepared for the additional role of infusing positive psychology ideas into the classroom.

Durlak (2008) posits that it is not enough for researchers to develop an intervention and expect it to be implemented effectively and widely. Rather researchers need to have knowledge of their target market by: understanding the obstacles and barriers inherent in school-based initiatives (Mohammadi et al., 2010); playing a larger role in the dissemination of research findings in forms accessible and appropriate for educators (Ahuja, 2012); and offering maintained support and assistance with implementation (Castro-Villarreal et al., 2014; Sanetti, Kratochwill, et al., 2013).

\section{Concluding thought}

The promise of universal implementation of positive psychology teaching in schools seems to be within our reach. However it will be up to the researchers of this 
generation to assure that this becomes a reality. From what we now know there is a clear link between psychological factors and positive youth development. Growing evidence is showing that school-based interventions rooted in various theoretical frameworks can produce positive effects for student achievement and mental health. The next step must see researchers stepping out of the comfort zone of a one-size fits all model of intervention, rather we should start to look across the field to create rich and varied programs to reflect the diversity of the youths we are trying to reach. Researchers of the future can no longer naively limit their work to intervention development to the detriment of investigation into effective implementation in real world settings. Schools and teachers are the true future of this discipline; they are the ones ultimately responsible for delivering positive psychology interventions and nurturing the healthy development of growing minds. We need to therefore start investing in high quality teacher training and support if we hope to one day have every school student benefiting from the teachings of positive-psychology ideas and techniques. 


\section{References}

Ahuja, S. (2012). Research Results for Quality Schooling: Bridging the Gap between Research and Practice. MIER Journal of Educational Studies, Trends and Practices, 2(2), 206-214.

American Psychiatric Association. (2013). Diagnostic and statistical manual of mental disorders (5th ed.). Washington, DC.

Arens, A. K., Yeung, A. S., Craven, R. G., \& Hasselhorn, M. (2011). The twofold multidimensionality of academic self-concept: Domain specificity and separation between competence and affect components. Journal of Educational Psychology, 103(4), 970. doi: 101.1037/a0025047

Askell-Williams, H., Dix, K. L., Lawson, M. J., \& Slee, P. T. (2013). Quality of implementation of a school mental health initiative and changes over time in students' social and emotional competencies. School Effectiveness and School Improvement, 24(3), 357-381. doi: 10.1080/09243453.2012.692697

Au, R. C., Watkins, D., Hattie, J., \& Alexander, P. (2009). Reformulating the depression model of learned hopelessness for academic outcomes. Educational Research Review, 4(2), 103-117. doi: 10.1016/j.edurev.2009.04.001

Au, R. C., Watkins, D. A., \& Hattie, J. A. (2010). Academic risk factors and deficits of learned hopelessness: a longitudinal study of Hong Kong secondary school students. Educational Psychology, 30(2), 125-138. doi:

$10.1080 / 01443410903476400$ 
Bakadorova, O., \& Raufelder, D. (2014). The mediating role of socio-motivational support in the association between individual school self-concept and achievement motivation amongst adolescent students. European Journal of Psychology of Education, 29(3), 347-366. doi: 10.1007/s10212-013-0202-5

Baker, R., Owens, M., Thomas, S., Whittlesea, A., Abbey, G., Gower, P., . . . Thomas, P. W. (2012). Does CBT facilitate emotional processing? Behavioural and cognitive psychotherapy, 40(01), 19-37. doi: $10.1017 / \mathrm{S} 1352465810000895$

Baker - Henningham, H., \& Walker, S. (2009). A qualitative study of teacher's perceptions of an intervention to prevent conduct problems in Jamaican pre schools. Child: care, health and development, 35(5), 632-642. doi: 10.1111/j.1365-2214.2009.00996.x

Bandura, A. (1978). Reflections on self-efficacy. Advances in behaviour research and therapy, 1(4), 237-269.

Banks, M., \& Woolfson, L. (2008). Why do students think they fail? The relationship between attributions and academic self - perceptions. British Journal of Special Education, 35(1), 49-56. doi: 10.1111/j.1467-8578.2008.00369.x

Baweja, S., Santiago, C. D., Vona, P., Pears, G., Langley, A., \& Kataoka, S. (2015). Improving Implementation of a School-Based Program for Traumatized Students: Identifying Factors that Promote Teacher Support and Collaboration. School Mental Health, 1-12. doi: DOI 10.1007/s12310-015-9170-z 
Bearman, S. K., Wadkins, M., Bailin, A., \& Doctoroff, G. (2015). Pre-practicum training in professional psychology to close the research-practice gap: Changing attitudes toward evidence-based practice. Training and Education in Professional Psychology, 9(1), 13-20. doi: 10.1037/tep0000052

Beets, M. W., Flay, B. R., Vuchinich, S., Acock, A. C., Li, K.-K., \& Allred, C. (2008). School climate and teachers' beliefs and attitudes associated with implementation of the positive action program: A diffusion of innovations model. Prevention Science, 9(4), 264-275. doi: 10.1007/s11121-008-0100-2

Berliner, D. C., \& Glass, G. V. (2014). 50 Myths and Lies That Threaten America's Public Schools: The Real Crisis in Education. New York: Teachers College Press, Columbia University.

Beycioglu, K., Ozer, N., \& Ugurlu, C. T. (2010). Teachers' views on educational research. Teaching and Teacher Education, 26(4), 1088-1093. doi: 10.1016/j.tate.2009.11.004

Blumer, C. (2015). What worries Australian children? BTN Happiness Survey finds 1 in 5 wouldn't talk about problems. $A B C$ News. Retrieved from http://www.abc.net.au/news/2015-10-05/btn-happiness-surveyaustralian-children-mental-health/6820652

Bodkin-Andrews, G., O'Rourke, V., \& Craven, R. G. (2010). The utility of general self-esteem and domain-specific self-concepts: Their influence on Indigenous and non-Indigenous students' educational outcomes. Australian Journal of Education, 54(3), 277-306. doi: 10.1177/000494411005400305 
Boiché, J., \& Stephan, Y. (2014). Motivational profiles and achievement: A prospective study testing potential mediators. Motivation and Emotion, 38(1), 79-92. doi: 10.1007/s11031-013-9361-6

Boonen, T., Pinxten, M., Van Damme, J., \& Onghena, P. (2013). Should schools be optimistic? An investigation of the association between academic optimism of schools and student achievement in primary education. Educational Research and Evaluation, 20(1), 3-24. doi: 10.1080/13803611.2013.860037

Borrelli, B. (2011). The assessment, monitoring, and enhancement of treatment fidelity in public health clinical trials. Journal of public health dentistry, 71(1), 52-63. doi: 10.1111/j.1752-7325.2011.00233.x

Bothe, D. A., Grignon, J. B., \& Olness, K. N. (2014). The effects of a stress management intervention in elementary school children. Journal of Developmental \& Behavioral Pediatrics, 35(1), 62-67. doi:

10.1097/DBP.0000000000000016

Boyle, C., \& Topping, K. (2012). What works in inclusion? London: McGraw-Hill International.

Boyle, C., Topping, K., Jindal-Snape, D., \& Norwich, B. (2011). The importance of peer-support for teaching staff when including children with special educational needs. School Psychology International, 33(2), 167-184. doi: $10.1177 / 0143034311415783$

Bradshaw, C. P., Koth, C. W., Thornton, L. A., \& Leaf, P. J. (2009). Altering school climate through school-wide Positive Behavioral Interventions and Supports: 
Findings from a group-randomized effectiveness trial. Prevention Science, 10(2), 100-115. doi: 10.1007/s11121-008-0114-9

Bronfenbrenner, U., \& Bronfenbrenner, U. (2009). The ecology of human development: Experiments by nature and design. Massachusetts: Harvard university press.

Casserly, A. M. (2013). The socio - emotional needs of children with dyslexia in different educational settings in Ireland. Journal of Research in Special Educational Needs, 13(1), 79-91. doi: 10.1111/j.1471-3802.2011.01227.x

Castro-Villarreal, F., Rodriguez, B. J., \& Moore, S. (2014). Teachers' perceptions and attitudes about Response to Intervention (RTI) in their schools: A qualitative analysis. Teaching and Teacher Education, 40, 104-112. doi:

10.1016/j.tate.2014.02.004

Cefai, C., \& Cavioni, V. (2015). Mental Health Promotion in School: An Integrated, School-Based, Whole School Promoting Psychological Well-Being in Children and Families (pp. 52-67). Hampshire: Springer.

Cheney, G., Schlösser, A., Nash, P., \& Glover, L. (2014). Targeted group-based interventions in schools to promote emotional well-being: A systematic review. Clinical child psychology and psychiatry, 19(3), 412-438. doi: $10.1177 / 1359104513489565$

Chodkiewicz, A., \& Boyle, C. (2015). Believing You Can is the First Step to Achieving: A CBT and Attribution Retraining Programme to Improve SelfBelief in Students aged 8-12. London: Jessica Kingsley Publishers. 
Chodkiewicz, A. R., \& Boyle, C. (2014). Exploring the contribution of attribution retraining to student perceptions and the learning process. Educational Psychology in Practice, 30(1), 78-87. doi: 10.1080/02667363.2014.880048

Coffey, J. K., Warren, M. T., \& Gottfried, A. W. (2014). Does infant happiness forecast adult life satisfaction? Examining subjective well-being in the first quarter century of life. Journal of Happiness Studies, 16(6), 1401-1421. doi: 10.1007/s10902-014-9556-X

Collins, S., Woolfson, L. M., \& Durkin, K. (2013). Effects on coping skills and anxiety of a universal school-based mental health intervention delivered in Scottish primary schools. School Psychology International, 35(1), 85-100. doi: 10.1007/s10902-014-9556-X

Connolly, S., Klenowski, V., \& Wyatt-Smith, C. M. (2012). Moderation and consistency of teacher judgement: teachers' views. British Educational Research Journal, 38(4), 593-614. doi: 10.1080/01411926.2011.569006

Council of Australian Governments (Producer). (2013). Council of Australian Governments National Action Plan for Mental Health 2006-2011. Retrieved from https://www.coag.gov.au/sites/default/files/NAP on Mental Health - Fourth Progress Report.pdf

Dawood, R. (2013). Positive Psychology in School-Based Psychological Intervention: A Study of the Evidence-Base. The European Journal of Social \& Behavioural Sciences, 5(2), 954-967. doi: 10.15405/ejsbs.70

De Castella, K., Byrne, D., \& Covington, M. (2013). Unmotivated or motivated to fail? A cross-cultural study of achievement motivation, fear of failure, and 
student disengagement. Journal of Educational Psychology, 105(3), 861-880. doi: $10.1037 / \mathrm{a} 0032464$

Department of Education NSW. (2015). Wellbeing for schools. Retrieved 31.10.2015, 2015, from https://www.det.nsw.edu.au/wellbeing

Department of Health and Ageing. (2013). National Mental Health Report 2013: tracking progress of mental health reform in Australia 1993-2011. Canberra: Commonwealth of Australia.

Diener, M. L., \& Lucas, R. E. (2004). Adults' Desires for Children's Emotions Across 48 Countries: Associations with Individual and National Characteristics. Journal of Cross-Cultural Psychology, 35(5), 525-547. doi: $10.1177 / 0022022104268387$

Dodge, R., Daly, A. P., Huyton, J., \& Sanders, L. D. (2012). The challenge of defining wellbeing. International Journal of Wellbeing, 2(3), 222-235. doi: 10.5502/ijw.v2i3.4

Drake, K., Belsky, J., \& Fearon, R. (2014). From early attachment to engagement with learning in school: The role of self-regulation and persistence. Developmental Psychology, 50(5), 1350. doi: 10.1037/a0032779

Dresel, M., \& Haugwitz, M. (2008). A computer-based approach to fostering motivation and self-regulated learning. The Journal of Experimental Education, 77(1), 3-20. doi: 10.3200/JEXE.77.1.3-20

Dubow, E. F., Huesmann, L. R., Boxer, P., Pulkkinen, L., \& Kokko, K. (2006). Middle childhood and adolescent contextual and personal predictors of adult 
educational and occupational outcomes: a mediational model in two countries. Developmental Psychology, 42(5), 937. doi: 10.1037/0012-1649.42.5.937

Durlak, J. A. (2015). Studying Program Implementation Is Not Easy but It Is Essential. Prevention Science, 16(8), 1123-1127. doi: 10.1007/s11121-0150606-3

Durlak, J. A., \& DuPre, E. P. (2008). Implementation matters: A review of research on the influence of implementation on program outcomes and the factors affecting implementation. American journal of community psychology, 41(34), 327-350. doi: 10.1007/s10464-008-9165-0

Durlak, J. A., Weissberg, R. P., Dymnicki, A. B., Taylor, R. D., \& Schellinger, K. B. (2011). The impact of enhancing students' social and emotional learning: A meta - analysis of school - based universal interventions. Child development, 82(1), 405-432. doi: 10.1111/j.1467-8624.2010.01564.x

Earhart, J., Jimerson, S. R., Eklund, K., Hart, S. R., Jones, C. N., Dowdy, E., \& Renshaw, T. L. (2009). Examining relationships between measures of positive behaviors and negative functioning for elementary school children. The California School Psychologist, 14(1), 97-104.

Evans, R., Murphy, S., \& Scourfield, J. (2015). Implementation of a School-Based Social and Emotional Learning Intervention: Understanding Diffusion Processes Within Complex Systems. Prevention Science, 16, 754-764. doi: $10.1007 / \mathrm{s} 11121-015-0552-0$. 
Fabiano, G. A., Chafouleas, S. M., Weist, M. D., Sumi, W. C., \& Humphrey, N. (2014). Methodology considerations in school mental health research. School Mental Health, 6(2), 68-83. doi: 10.1007/s12310-013-9117-1

Fisher, L. (2014). Foundations of children's self-concepts about everyday activities: Identities and comparative contexts. European Journal of Psychology of Education, 29(3), 537-555. doi: 10.1007/s10212-014-0212-y

Forman, S. G., Olin, S. S., Hoagwood, K. E., Crowe, M., \& Saka, N. (2009). Evidence-based interventions in schools: Developers' views of implementation barriers and facilitators. School Mental Health, 1(1), 26-36. doi: $10.1007 / \mathrm{s} 12310-008-9002-5$

Fowler, R. D., Seligman, M. E. P., \& Koocher, G. P. (1999). The APA 1998 Annual Report. American Psychologist, 54(8), 537-568. doi: 10.1037/0003066X.54.8.537

Frawley, A. (2015). Happiness Research: A Review of Critiques. Sociology Compass, 9(1), 62-77. doi: 10.1111/soc4.12236

Froh, J. J., Kashdan, T. B., Ozimkowski, K. M., \& Miller, N. (2009). Who benefits the most from a gratitude intervention in children and adolescents? Examining positive affect as a moderator. The Journal of Positive Psychology, 4(5), 408422. doi: $10.1080 / 17439760902992464$

Froh, J. J., Sefick, W. J., \& Emmons, R. A. (2008). Counting blessings in early adolescents: An experimental study of gratitude and subjective well-being. Journal of school psychology, 46(2), 213-233. doi: 10.1016/j.jsp.2007.03.005 
Fyrstén, S., Nurmi, J.-E., \& Lyytinen, H. (2006). The role of achievement beliefs and behaviours in spontaneous reading acquisition. Learning and Instruction, 16(6), 569-582. doi: 10.1016/j.learninstruc.2006.10.005

Galassi, J. P., \& Akos, P. (2004). Developmental Advocacy: Twenty - First Century School Counseling. Journal of Counseling \& Development, 82(2), 146-157. doi: 10.1002/j.1556-6678.2004.tb00296.x

Gut, J., Reimann, G., \& Grob, A. (2013). A contextual view of long-term predictors of academic performance. . Journal of Educational Psychology, 105(2), 436443. doi: $10.1037 / \mathrm{a} 0031503$

Hallam, S. (2009). An evaluation of the Social and Emotional Aspects of Learning (SEAL) programme: promoting positive behaviour, effective learning and well - being in primary school children. Oxford Review of Education, 35(3), 313-330. doi: 10.1080/03054980902934597

Harter, S. (1982). The perceived competence scale for children. Child development, 53(1), 87-97. doi: 10.2307/1129640

Holen, S., Lervåg, A., Waaktaar, T., \& Ystgaard, M. (2012). Exploring the associations between coping patterns for everyday stressors and mental health in young schoolchildren. Journal of school psychology, 50(2), 167-193. doi: 10.1016/j.jsp.2011.10.006

Horn, A. B., Pössel, P., \& Hautzinger, M. (2011). Promoting Adaptive Emotion Regulation and Coping in Adolescence A School-based Programme. Journal of health psychology, 16(2), 258-273. doi: 10.117/1359105310372814 
Horner, S. L., \& Gaither, S. M. (2004). Attribution retraining instruction with a second-grade class. Early Childhood Education Journal, 31(3), 165-170.

Huebner, S., \& Kimberly, H. (2011). Does the positive psychology movement have legs for children in schools? The Journal of Positive Psychology, 6(1), 88-94. doi: $10.1080 / 17439760.2010 .536778$

Huppert, F. A., \& Johnson, D. M. (2010). A controlled trial of mindfulness training in schools: The importance of practice for an impact on well-being. The Journal of Positive Psychology, 5(4), 264-274. doi: 10.1080/17439761003794148

Hursh, D. W. (2008). High-stakes testing and the decline of teaching and learning: The real crisis in education (Vol. 1). Washington: Rowman \& Littlefield.

Jones, S. M., \& Bouffard, S. M. (2012). Social and Emotional Learning in Schools: From Programs to Strategies. Social Policy Report. . Society for Research in Child Development, 26(4), 1-13. doi: 10.1037/a0025596

Kirkpatrick, B. L. (Producer). (2015). Personality and Happiness. Retrieved from http://digital.sandiego.edu/honors theses/3

Kuperminc, G. P., Thomason, J., DiMeo, M., \& Broomfield-Massey, K. (2011). Cool Girls, Inc.: Promoting the positive development of urban preadolescent and early adolescent girls. The journal of primary prevention, 32(3-4), 171-183. doi: 10.1007/s10935-011-0243-y

Lavasani, M., Sharifian, M., Naghizadeh, S., \& Hematirad, G. (2012). The effect of attribution retraining on academic achievement. Procedia: Social and Behavioral Sciences, 46, 5845-5848. doi: 10.1016/j.sbspro.2012.06.526 
Lawrence, D., Johnson, S., Hafekost, J., Hann, K. B. d., Sawyer, M., Ainley, J., \& Zubrick, S. (2015). The Mental Health of Children and Adolescents: Report on the second Australian Child and Adolescent Survey of Mental Health and Wellbeing. Canberra: Department of Health.

Lazarus, R. S. (2003). TARGET ARTICLE: Does the Positive Psychology Movement Have Legs? Psychological Inquiry, 14(2), 93-109. doi: 10.1207/S15327965PLI1402_02

Lerner, R. M., von Eye, A., Lerner, J. V., Lewin-Bizan, S., \& Bowers, E. P. (2010). Special issue introduction: The meaning and measurement of thriving: A view of the issues. Journal of Youth and Adolescence, 39(7), 707-719. doi: $10.1007 / \mathrm{s} 10964-010-9531-8$

Lewis, A. D., Huebner, E. S., Malone, P. S., \& Valois, R. F. (2011). Life satisfaction and student engagement in adolescents. Journal of Youth and Adolescence, 40(3), 249-262. doi: 10.1007/s10964-010-9517-6

Lewis, A. D., Huebner, E. S., Reschly, A. L., \& Valois, R. F. (2009). The incremental validity of positive emotions in predicting school functioning. Journal of Psychoeducational Assessment, 27(5), 397-408. doi: $10.1177 / 0734282908330571$

Lipsitz, J. S. (1977). Growing up forgotten: A review of research and programs concerning young adolescents. New Jersey: Transaction Books.

Lundqvist, C., \& Kenttä, G. (2010). Positive emotions are not simply the absence of the negative ones: Development and validation of the Emotional Recovery Questionnaire (EmRecQ). The Sport Psychologist, 24(4), 468-488. 
Lyubomirsky, S. (2007). The how of happiness: A new approach to getting the life you want. New York: Penguin.

Madden, W., Green, S., \& Grant, A. M. (2011). A pilot study evaluating strengthsbased coaching for primary school students: Enhancing engagement and hope. International Coaching Psychology Review, 6(1), 71-83.

Marques, S. C., Pais-Ribeiro, J. L., \& Lopez, S. J. (2011). The role of positive psychology constructs in predicting mental health and academic achievement in children and adolescents: A two-year longitudinal study. Journal of Happiness Studies, 12(6), 1049-1062. doi: 10.1007/s10902-010-9244-4

Marsh, H. W., Abduljabbar, A. S., Morin, A. J. S., Parker, P., Abdelfattah, F., Nagengast, B., \& Abu-Hilal, M. M. (2015). The big-fish-little-pond effect: Generalizability of social comparison processes over two age cohorts from Western, Asian, and Middle Eastern Islamic countries. Journal of Educational Psychology, 107(1), 258-271. doi: 10.1037/a0037485

Martin, A. J. (2007). Examining a multidimensional model of student motivation and engagement using a construct validation approach. British Journal of Educational Psychology, 77(2), 413-440. doi: 10.1348/000709906X118036

Martin, A. J. (2009). Motivation and engagement across the academic life span: A developmental construct validity study of elementary school, high school, and university/college students. Educational and Psychological Measurement, 69(5), 794-824. doi: 10.1177/0013164409332214

Martin, A. J., Nejad, H. G., Colmar, S., \& Liem, G. A. D. (2013). Adaptability: How students' responses to uncertainty and novelty predict their academic and non- 
academic outcomes. Journal of Educational Psychology, 105(3), 728-746. doi: $10.1037 / \mathrm{a} 0032794$

Maslow, A. H. (1954). Personality and motivation. England: Longman.

Miller, A. (2008). A critique of positive psychology-or ' the new science of happiness' . Journal of Philosophy of Education, $42(3$ - 4), 591-608. doi: $10.1111 / \mathrm{j} .1467-9752.2008 .00646 . \mathrm{x}$

Miller, L. D., Short, C., Garland, E. J., \& Clark, S. (2010). The ABCs of CBT (cognitive behavior therapy): Evidence-based approaches to child anxiety in public school settings. Journal of Counseling \& Development, 88(4), 432-439. doi: 10.1002/j.1556-6678.2010.tb00043.x

Mohammadi, N. K., Rowling, L., \& Nutbeam, D. (2010). Acknowledging educational perspectives on health promoting schools. Health Education, 110(4), 240-251. doi: 10.1108/09654281011052619

Morris, M. (2013). A naturalistic investigation into the effectiveness of an attributional retraining progromme for academic performance. . Social Sciences Directory, 2(2), 16-30. doi: 10.7563/SSD_02_02_02

Mulnix, J. W., \& Mulnix, M. J. (2015). Happy Lives, Good Lives: A Philosophical Examination. Toronto: Broadview Press.

Mychailyszyn, M. P., Brodman, D. M., Read, K. L., \& Kendall, P. C. (2012). Cognitive - Behavioral School - Based Interventions for Anxious and Depressed Youth: A Meta - Analysis of Outcomes. Clinical Psychology: Science and Practice, 19(2), 129-153. doi: 10.1111/j.1468-2850.2012.01279.x 
Neil, A. L., \& Christensen, H. (2009). Efficacy and effectiveness of school-based prevention and early intervention programs for anxiety. Clinical psychology review, 29(3), 208-215. doi: 10.1016/j.cpr.2009.01.002

Nidich, S., Mjasiri, S., Nidich, R., Rainforth, M., Grant, J., Valosek, L., . . Zigler, R. L. (2011). Academic achievement and transcendental meditation: A study with at-risk urban middle school students. Education, 131(3), 556.

Nielsen, L., Meilstrup, C., Nelausen, M. K., Koushede, V., Holstein, B. E., Weare, K., \& Weare, K. (2015). Promotion of social and emotional competence: experiences from a mental health intervention applying a whole school approach. Health Education, 115(3/4), 339-356. doi: 10.1108/HE-03-20140039

Norton, A., \& Cherastidtham, I. (Producer). (2014). Mapping Australian higher education, 2014-15. Retrieved from http://grattan.edu.au/wpcontent/uploads/2014/10/816-mapping-higher-education-2014.pdf

Núñez, J. C., González - Pienda, J. A., González - Pumariega, S., Roces, C., Alvarez, L., González, P., . . Rodríguez, S. (2005). Subgroups of attributional profiles in students with learning difficulties and their relation to self - concept and academic goals. Learning Disabilities Research \& Practice, 20(2), 86-97. doi: 10.1111/j.1540-5826.2005.00124.x

O’Connor, M., Sanson, A., Hawkins, M. T., Letcher, P., Toumbourou, J. W., Smart, D., ... Olsson, C. A. (2011). Predictors of positive development in emerging adulthood. Journal of Youth and Adolescence, 40(7), 860-874. doi: $10.1007 / \mathrm{s} 10964-010-9593-7$ 
Oades, L. G., Robinson, P., \& Green, S. (2011). Positive education: creating flourishing students, staff and schools. InPsych: The Bulletin of the Australian Psychological Society Ltd, 33(2), 16-17.

Ohl, M., Fox, P., \& Mitchell, K. (2013). Strengthening socio - emotional competencies in a school setting: Data from the Pyramid project. British Journal of Educational Psychology, 83(3), 452-466. doi: 10.1111/j.20448279-2012.02074.x

Owens, J. S., \& Murphy, C. E. (2004). Effectiveness research in the context of school-based mental health. Clinical Child and Family Psychology Review, 7(4), 195-209.

Owens, R. L., \& Patterson, M. M. (2013). Positive psychological interventions for children: A comparison of gratitude and best possible selves approaches. The Journal of genetic psychology, 174(4), 403-428. doi:

$10.1080 / 00221325.2012 .697496$

Pas, E. T., \& Bradshaw, C. P. (2012). Examining the association between implementation and outcomes. The journal of behavioral health services \& research, 39(4), 417-433.

Peterson, C., \& Seligman, M. E. (2004). Character strengths and virtues: A handbook and classification. Washington: Oxford University Press.

Pinxten, M., Marsh, H. W., De Fraine, B., Van Den Noortgate, W., \& Van Damme, J. (2014). Enjoying mathematics or feeling competent in mathematics? Reciprocal effects on mathematics achievement and perceived math effort 
expenditure. British Journal of Educational Psychology, 84(1), 152-174. doi: 10.1111/bjep. 12028

Pinxten, M., Wouters, S., Preckel, F., Niepel, C., De Fraine, B., \& Verschueren, K. (2015). The formation of academic self-concept in elementary education: A unifying model for external and internal comparisons. Contemporary Educational Psychology, 41, 124-132. doi: 10.1016/j.cedpsych.2014.12.003

Polesel, J., Dulfer, N., \& Turnbull, M. (Producer). (2012). The experience of education: The impacts of high stakes testing on school students and their families. Sydney: Whitlam Insititute. Retrieved from http://www.whitlam.org/ data/assets/pdf file/0010/409735/High Sta kes Testing An Educators Perspective.pdf

Popham, W. J. (2001). Teaching to the Test? Educational leadership, 58(6), 16-21.

Powers, J. D., Bowen, N. K., \& Bowen, G. L. (2010). Evidence-based programs in school settings: Barriers and recent advances. Journal of evidence-based social work, 7(4), 313-331. doi: 10.1080/154337109032566807

Punamäki, R.-L., Paavonen, J., Toikka, S., \& Solantaus, T. (2013). Effectiveness of preventive family intervention in improving cognitive attributions among children of depressed parents: a randomized study. Journal of Family Psychology, 27(4), 683. doi: 10.1037/a0033466

Reynolds, S., Wilson, C., Austin, J., \& Hooper, L. (2012). Effects of psychotherapy for anxiety in children and adolescents: A meta-analytic review. Clinical psychology review, 32(4), 251-262. doi: 10.1016/j.cpr.2012.01.005 
Richards, M., \& Huppert, F. A. (2011). Do positive children become positive adults? Evidence from a longitudinal birth cohort study. The Journal of Positive Psychology, 6(1), 75-87. doi: 10.1080/17439760.2011.536655

Richardson, M., Abraham, C., \& Bond, R. (2012). Psychological correlates of university students' academic performance: a systematic review and metaanalysis. Psychological Bulletin, 138(2), 353. doi: 10.1037/a0026838

Roberts, C. M., Kane, R., Bishop, B., Cross, D., Fenton, J., \& Hart, B. (2010). The prevention of anxiety and depression in children from disadvantaged schools. Behaviour research and therapy, 48(1), 68-73. doi:

10.1016/j.brat.2009.09.002

Rudalevige, A. (Producer). (2003). No Child Left Behind. No child left behind. Retrieved from http://media.hoover.org/sites/default/files/documents/ednext20034 6 2.pdf

Sandage, S. J., \& Hill, P. C. (2001). The virtues of positive psychology: The rapprochement and challenges of an affirmative postmodern perspective. Journal for the Theory of Social Behaviour, 31(3), 241-260. doi: $10.1111 / 1468-5914.00157$

Sanetti, L., Dobey, L. M., \& Gallucci, J. (2013). Treatment integrity of interventions with children in School Psychology International from 1995-2010. School Psychology International, 35(4), 370-383. doi: 10.1177/0143034313476399 
Sanetti, L., Kratochwill, T., \& Long, A. (2013). Applying adult behavior change theory to support mediator-based intervention implementation. School Psychology Quarterly, 28(1), 47-62. doi: 10.1037/spq0000007

Schonert-Reichl, K. A., Oberle, E., Lawlor, M. S., Abbott, D., Thomson, K., Oberlander, T. F., \& Diamond, A. (2015). Enhancing cognitive and socialemotional development through a simple-to-administer mindfulness-based school program for elementary school children: A randomized controlled trial. Developmental Psychology, 51(1), 52-66. doi: 10.1007/s10964-009-9486-9.

Schuitema, J., Peetsma, T., \& van der Veen, I. (2014). Enhancing Student Motivation: A Longitudinal Intervention Study Based on Future Time Perspective Theory. The Journal of Educational Research, 107(6), 467-481. doi: $10.1080 / 00220671.2013 .836467$

Schwinger, M., Wirthwein, L., Lemmer, G., \& Steinmayr, R. (2014). Academic selfhandicapping and achievement: A meta-analysis. Journal of Educational Psychology, 106(3), 744-761. doi: 10.1037/a0035832

Seligman, M. E. (2002). Positive psychology, positive prevention, and positive therapy. Handbook of positive psychology, 2, 3-12.

Seligman, M. E., Ernst, R. M., Gillham, J., Reivich, K., \& Linkins, M. (2009). Positive education: Positive psychology and classroom interventions. Oxford Review of Education, 35(3), 293-311. doi: 10.1080/03054980902034563 
Seligman, M. E., Railton, P., Baumeister, R. F., \& Sripada, C. (2013). Navigating into the future or driven by the past. Perspectives on Psychological Science, $8(2)$, 119-141. doi: $10.1177 / 1745691612474317$

Seligman, M. E., Reivich, K., Jaycox, L., Gillham, J., \& Kidman, A. D. (1995). The optimistic child. New York: Houghton Mifflin

Seligman, M. E., Schulman, P., \& Tryon, A. M. (2007). Group prevention of depression and anxiety symptoms. Behaviour research and therapy, 45(6), 1111-1126. doi: 10.1016/j.brat.2006.09.010

Sin, N. L., \& Lyubomirsky, S. (2009). Enhancing well - being and alleviating depressive symptoms with positive psychology interventions: A practice friendly meta - analysis. Journal of clinical psychology, 65(5), 467-487. doi: 10.1002/jclp.20593

Spielmans, G. I., Pasek, L. F., \& McFall, J. P. (2007). What are the active ingredients in cognitive and behavioral psychotherapy for anxious and depressed children? A meta-analytic review. Clinical psychology review, 27(5), 642-654. doi: 10.1016/j.cpr.2006.06.001

Stevenson, I. (2013). Does technology have an impact on learning? A Fuzzy set analysis of historical data on the role of digital repertoires in shaping the outcomes of classroom pedagogy. Computers \& Education, 69, 148-158. doi: 10.1016/j.compedu.2013.07.010

Stice, E., Rohde, P., Gau, J. M., \& Wade, E. (2010). Efficacy trial of a brief cognitive-behavioral depression prevention program for high-risk adolescents: 
Effects at 1-and 2-year follow-up. Journal of Consulting and Clinical Psychology, 78(6), 856. doi: 10.1037/a0020544

Suldo, S. M., Savage, J. A., \& Mercer, S. H. (2014). Increasing middle school students' life satisfaction: Efficacy of a positive psychology group intervention. Journal of Happiness Studies, 15(1), 19-42. doi: $10.1007 / \mathrm{s} 10902-013-9414-2$

Terjesen, M. D., Jacofsky, M., Froh, J., \& Digiuseppe, R. (2004). Integrating positive psychology into schools: Implications for practice. Psychology in the Schools, 41(1), 163-172. doi: 10.1002/pits. 10148

Toland, J., \& Boyle, C. (2008). Applying cognitive behavioural methods to retrain children's attributions for success and failure in learning. School Psychology International, 29(3), 286-302. doi: 10.1177/0143034308093674

Urhahne, D., Chao, S. H., Florineth, M. L., Luttenberger, S., \& Paechter, M. (2011). Academic self - concept, learning motivation, and test anxiety of the underestimated student. British Journal of Educational Psychology, 81(1), 161-177. doi: 10.1348/000709910X504500

Vella-Brodrick, D. A. (2011). Positive psychology: Reflecting on the past and projecting into the future. InPsych: The Bulletin of the Australian Psychological Society Ltd, 33(2), 10-13.

Waters, L. (2011). A review of school-based positive psychology interventions. The Australian Educational and Developmental Psychologist, 28(2), 75-90. doi: 10.1375/aedp.28.2.75 
Weiner, B. (1979). A theory of motivation for some classroom experiences. Journal of Educational Psychology, 71(1), 3-25. doi: 10.1037/0022-0663.71.1.3

Weiner, B. (2010). The development of an attribution-based theory of motivation: A history of ideas. Educational Psychologist, 45(1), 28-36. doi: $10.1080 / 00461520903433596$

Weissberg, R. P., Kumpfer, K. L., \& Seligman, M. E. (2003). Prevention that works for children and youth: An introduction. American Psychologist, 58(6-7), 425432. doi: 10.1037/0003-066X.58.6-7.425

Whitley, A., Huebner, E. S., Hills, K., \& Valois, R. (2012). Can Students be Too Happy in School? The Optimal Level of School Satisfaction. Applied Research in Quality of Life, 7(4), 337-350. doi: 10.1007/s11482-012-9167-9

Woods, R., \& Pooley, J. A. (2015). A review of intervention programs that assist the transition for adolescence into high school and the prevention of mental health problems. International Journal of Child and Adolescent Health, 8(2), 97.

Wyn, J., Cahill, H., Holdsworth, R., Rowling, L., \& Carson, S. (2000). MindMatters, a whole - school approach promoting mental health and wellbeing. Australian and New Zealand Journal of Psychiatry, 34(4), 594-601. doi: 10.1080/j.14401614.2000.00748.x

Yeung, A. S., Craven, R. G., \& Kaur, G. (2014). Influences of Mastery Goal and Perceived Competence on Educational Outcomes. Australian Journal of Educational \& Developmental Psychology, 14, 117-130. 
Yu, K., \& Martin, A. J. (2014). Personal best (PB) and 'classic'achievement goals in the Chinese context: their role in predicting academic motivation, engagement and buoyancy. Educational Psychology, 34(5), 635-658. doi:

$10.1080 / 01443410.2014 .895297$

Ziegler, A., \& Heller, K. A. (2000). Effects of an attribution retraining with female students gifted in physics. Journal for the Education of the Gifted, 23(2), 217243. doi: $10.4219 /$ jeg-2000-572

Zimmerman, S. M., Phelps, E., \& Lerner, R. M. (2008). Positive and negative developmental trajectories in US adolescents: Where the positive youth development perspective meets the deficit model. Research in Human Development, 5(3), 153-165. doi: 10.1080/15427600802274001 